REFLECTIONS:

NEUROLOGY AND THE

HUMANITIES

Section Editor

Michael H. Brooke, MD

\title{
The art of knowing
}

"No, just no better than she was to start with. She

James Gordon, MD, FRCPC, FAAN

Address correspondence and reprint requests to Dr. James Gordon, University of Washington, Northwest Hospital and Medical Center, $1570 \mathrm{~N}$. 115 th St., Suite 14, Seattle, WA 98133 neurojim@yahoo.com
Alou was meant to have died months before he did. By the time he was diagnosed with stomach cancer, they couldn't get an endoscope past his pylorus, but somehow he hung on. We watched, we waited, we worried, we fretted, we wondered what to do, but nothing seemed to happen. And the longer we hovered, the harder it was to relinquish the delusion that what seems undeniable might be untrue, that what we knew to be true might turn out to be all wrong. Samuel Johnson missed half the point when he said that the prospect of death concentrates the mind. Sometimes, it just makes you fixate. Sometimes, you can't see clearly until you're so exhausted you can no longer think.

That last couple of weeks, Alou was pretty much the only thing on my mind.

Shortly before he died, I was called to the ER see an old woman who'd had a seizure at lunch in her nursing home. In the cubicle, her daughter sat quietly at the bedside, fidgeting with a living will her mother had filled out a couple of years before, when she still could.

"It's kind of hard to know what to do," I said. "I guess she was pretty clear about what she wanted, but-"

"She'd hate being like this," she said.

"I know what you mean," I said, "but we don't really know what's wrong. I mean, she had a seizure, it's been 6 hours, she's still confused, and she has a fever. We don't know why. The fever, I mean. In situations like this, we usually recommend a spinal tap. To be sure she doesn't have meningitis-"

"I don't think she'd want this."

"It's really not a big deal. Not much worse than a blood test."

"What are the odds she'll get better?"

"Hard to say. If she's got meningitis, she's likely to be worse than she was before. If she's just recovering from a seizure, she's likely to be back to her old self, more or less, eventually. As long as nothing else happens. No complications, I mean. Like pneumonia or a urinary infection or bedsores-"

"She won't get any better." certainly could recover from whatever's going on right now."

"Does it matter?" she said.

"What?"

"That she gets better."

"You mean-"

"Her life is over," she said. "She would have hated this."

"Well, we're sort of stuck," I said. "I mean, here she is. If it's just a little infection, she really could get back to where she was. I mean, were things really that bad?"

"No. I don't know. Maybe. I don't know. Maybe that's not the point. I don't know. This isn't what she wanted. It isn't what she wanted."

This was taking time, and it was late, and I had to get home to Alou.

"Maybe we can talk some more tomorrow. We just won't do anything stupid for the night, okay? No ventilators or pumping on her chest or anything. We can talk some more tomorrow. Would that be okay?"

She nodded without conviction, and I left. Alou was waiting. I had no choice.

By the end, my life revolved around him completely. Because Louise was away visiting the girls, everything fell to me. At first I felt guilty, as if I were abandoning him when I'd drop him at daycare on the way to work. When he ended up loving it there, you'd think it might have made me feel better, but watching him bounce down the stairs at the end of the day just rubbed salt in the wound. Ultimately, I suppose, his contentment in daycare those last days did make it easier to clean up his mess at home, easier to accept the incontrovertible fact that he ate less every day and left most of that on the carpet while the rest of us slept.

And he never lost his good humor, never stopped being good company. It was no wonder that Louise adored him so-more than me, probably.

Early on, we'd been concerned that things might come suddenly, painfully, that something awful might happen in the middle of the night, so we made 
an appointment to talk it over with Dr. B. He tried to reassure us by telling us that there's usually nothing dramatic - that somehow you just know. We had little choice but to believe him, but there was little comfort in what he said. I suppose there wouldn't have been much comfort in anything he could have said.

Of course, in the end he was right. It was impossible not to know.

That last day at daycare, they called me at work to tell me that Alou was canting and that they'd had to take him aside and swaddle him in blankets. He was still drinking, but he wouldn't eat a thing. It was rough seeing him like that: the handsomest, the most elegant guy on the block-crippled, hobbling halfsideways down the stairs, studying each step as if it would disintegrate if he were to look away. And when he came to me and I stroked his head, his skull and his spine seemed suddenly igneous-petrified, sharp, jagged-palpably uncushioned by muscle or fat. Beneath my fingers, his withered ribcage rippled like a marimba worn smooth by decades of play. $\mathrm{He}$ lifted his face to me, and his nose was warm and dry and rough.

At least he could still climb into the car on his own. I was grateful for that.

I went to work the next day. The old woman was still confused, but her fever was gone. The nursing home was prepared to take her back, even in this condition. Her daughter had never left her side. She had spoken to her brother and sister, and there was no disagreement. There would be no lumbar puncture, no antibiotics, no feeding tube, even if she couldn't eat. They weren't going to drag her back. She knew, and we knew. And that was that.

The night before, I'd tried everything: eggs, salmon, baby food, chicken, cheese, applesauce, mashed potatoes, crushed bananas, pureed pears. I even opened a can of chicken noodle soup, but he wouldn't touch it. Each time I'd place the dish in front of him, he'd be drawn as if by instinct, and then he'd cringe and recoil, repelled like a like-poled magnet.

The next morning, his water bowl hadn't been touched. That afternoon, when I got home from the hospital, the kitchen chairs and table had been moved from their usual spot near the door. Alou was asleep on the couch.

"He threw up all over the place," Aaron said.

"Looks like he tried to get outside," I said.

"Yeah. I cleaned it up."
"Didn't make it."

"It was gross. All watery. And yellow."

"That's bile. There was probably nothing else in his stomach."

"There were some pills on the floor."

"Probably what I gave him yesterday."

I went over to the couch where Alou lay.

"I think it's time, dad."

"Yeah. I was just hoping we could hold out till mom got home."

"I don't think so, dad. Even I can tell."

Two months earlier, we'd thought it was over. Louise had to go away, and we hadn't found daycare yet, so Alou was alone all day for 2 weeks. I'd run home at lunchtime to feed him and let him out, but by the second week he wouldn't even come to the door. By the time she got back, he would hardly leave the couch. We were so sure he was about to die that when the time came for Aaron's college trip, Louise just dropped us at the curb and dashed home in tears, determined to do at last what needed to be done. She called her friend, Jan, so she wouldn't have to be alone. And the minute Jan knocked on the door, Alou jumped off the couch, and off they went for a muffin.

That was when I began to question the diagnosis. Biopsy or no biopsy, it was almost impossible to believe that he was dying.

Now things were different. Undeniably. Though he'd hardly eaten or drunk a thing for more than a day, he still couldn't keep anything down, not even what his body produced on its own. And when he wasn't just lying there, he'd pace and lick his teeth the way he used to as a puppy, when he'd throw up any time he had to ride in the back of the car.

"Will you go with me?" I asked.

"Of course."

This time was different. Even Aaron could tell.

"What do you say we bring him to Tully's?" I said, hopeful.

"For a muffin?" said Aaron.

"Sure. Why not?"

"Sure."

We took off for the corner. At first Alou seemed content to come along, to sniff the azaleas and rhododendrons, so familiar on the front walk. He trudged from bush to bush, pausing at widening intervals in a waning, futile effort to leave his mark. Gradually, inevitably, he surrendered, and by the 
time we got to Tully's, an eager puppy at the front door-a spectacular ball of vibrant golden fur that would have captivated him for hours only a few days before-prompted little more than a shrug before he turned back to lean quietly against my leg.

We tried the muffin. I crumbled it in my hand, and then in Aaron's, but he wouldn't even nibble. There would be no reprieve. We turned to the door.

Alou dug in his heels. Maybe he was too tired to walk up the little hill, or maybe he was too weak, or maybe it was too far, or maybe it was that he knew where he was going. I don't know. But he wouldn't budge.

A few minutes later, I lifted Alou into the front seat with me, and I recall being stunned by his lightness - the way you feel when you pick up a box and smack yourself in the face when it turns out to be more shell than substance. I remember wondering how much he weighed as I belted him snug in my lap. It's funny the things you think about.

We walked into Dr. B's waiting room, Alou between Aaron and me. Everyone knew why we were there. In the back room, the attendant lifted him onto a steel table they'd warmed and covered with a soft plaid comforter.

Dr. B stroked him gently. "You know," he said, "it's amazing he's lasted this long."

"You told us we'd know," I said. "I wondered about that. But you were right."

"His coat is just lovely," he said.

"Probably all that people food," I said. I could hardly speak.

He stroked him and felt for a vein and kept stroking as he shaved a spot on his foreleg.

"You know," he said, "As I get older, the longer I live, I just get more and more cynical about so many things. But at times like these it never ceases to amaze me how sensible people are, how much common sense they have when it comes to their pets."

The attendant gathered Alou tenderly in her arms.

Dr. B slipped the needle into his leg, and in a minute it was over. He didn't leave the room. It was good that he wasn't a stranger. 


\title{
Neurology
}

\author{
The art of knowing \\ James Gordon \\ Neurology 2008;71;1456-1458 \\ DOI 10.1212/01.wnl.0000327878.71122.c0
}

This information is current as of October 27, 2008

\section{Updated Information \& Services}

Subspecialty Collections

Permissions \& Licensing

Reprints including high resolution figures, can be found at: http://n.neurology.org/content/71/18/1456.full

This article, along with others on similar topics, appears in the following collection(s):

All Ethics in Neurology/Legal issues

http://n.neurology.org/cgi/collection/all_ethics_in_neurology_legal_iss ues

Information about reproducing this article in parts (figures,tables) or in its entirety can be found online at:

http://www.neurology.org/about/about_the_journal\#permissions

Information about ordering reprints can be found online:

http://n.neurology.org/subscribers/advertise

Neurology ${ }^{\circledR}$ is the official journal of the American Academy of Neurology. Published continuously since 1951, it is now a weekly with 48 issues per year. Copyright. All rights reserved. Print ISSN: 0028-3878. Online ISSN: 1526-632X.

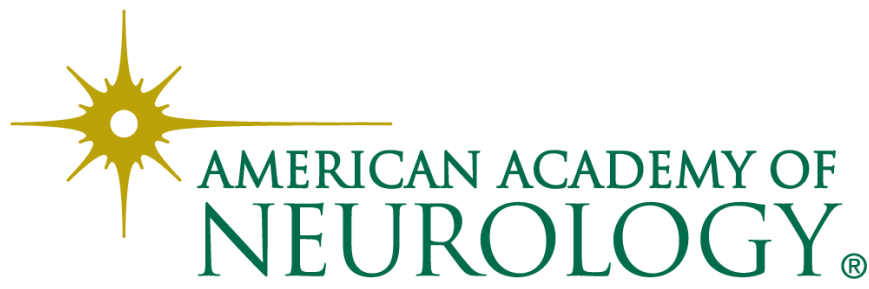

